\title{
The fate of small-mammal carrion is affected by carcass size and visual conspicuousness in a Neotropical rainforest
}

\author{
ANDREA ROMERO ${ }^{1 *}$ \\ ${ }^{1}$ Department of Biological Sciences and Department of Geography, Geology, and Environmental Science, University of Wisconsin- \\ Whitewater. 800 W Main St. Whitewater, WI 53190 U.S.A. Email: romeroa@gmail.com (AR). \\ *Corresponding author
}

\begin{abstract}
Scavenging of carrion is essential to terrestrial ecosystems and can shape food webs and behavior. The prevalence and importance of scavenging has often been underestimated and overlooked in food web studies. Small-mammal carrion is even less studied and difficult to estimate, especially in the Neotropics. This project explored small-mammal carcass scavenging in a Neotropical, mid-elevation rainforest, and specifically studied the rate of carcass removal by scavengers, how the conspicuousness and weight of carcasses affect scavenging, and what vertebrate scavengers utilize this carrion resource. I deployed 194 mouse carcasses of various weights, above and below the leaf litter, and surveyed them daily until disappearance. I paired each carcass with a trail camera to help identify vertebrate scavengers. A general linear model analysis showed that most mouse carcasses disappeared within 1 to 2 days. Carcasses above the leaf litter were removed quicker and larger mice generally lasted longer. Only $6.25 \%$ of the carcasses were removed by vertebrates. Most carcasses were removed by something too small to trigger the trail cameras, likely scarab beetles. The results of this study show that small-mammal carcasses are a sought-after resource in Neotropical forests, and that invertebrates are able to quickly hoard and secure small carrion more efficiently than vertebrate scavengers. A better understanding of scavenging ecology in Neotropical forests will help in developing a broader framework of the trophic interactions within and across ecosystems.
\end{abstract}

El consumo de carroña es esencial en los ecosistemas terrestres e influye en la estructura de redes tróficas, así como la conducta animal. A pesar de eso, este es un aspecto poco estudiado en los estudios de redes alimentarias. El papel que juega la carroña de mamíferos pequeños ha sido aún menos estudiada y muy difícil de estimar, especialmente en el Neotrópico. En este estudio investigamos la recolección de carroña por parte de pequeños mamíferos en un bosque lluvioso neotropical de elevación media. Estudiamos específicamente la tasa de recogida de cadáveres por parte de los carroñeros, así como lo conspicuo y el peso de la carroña y como esos factores afectan su recolección, y qué recolectores de vertebrados utilizan la carroña. Con tal fin se colocaron 194 carroñas de ratones de peso variado, tanto encima como debajo de la hojarasca, y se examinaron diariamente hasta su desaparición. Se colocó una cámara video apuntando a cada carroña para ayudar a identificar los carroñeros de los vertebrados. Un análisis general de tipo lineal mostró que la mayoría de la carroña de ratones desaparecieron entre 1 y 2 días. La carroña por encima de la hojarasca se consumió más rápido y la carroña de mayor tamaño generalmente duró más. Sólo el 6.25 \% de la carroña fue removida por vertebrados. La mayoría de la carroña fue removida por agentes demasiado pequeños para activar las cámaras y sospechamos que esos agentes eran escarabajos. Los resultados de este estudio sugieren que la carroña de mamíferos pequeños son un recurso esencial en los bosques neotropicales, y que los invertebrados pueden acumular y renovar rápidamente carroña pequeña de manera más eficiente que los vertebrados carroñeros. Una mejor comprensión de la ecología del carroñerismo en los bosques neotropicales ayudará a desarrollar un marco más amplio de las interacciones tróficas dentro y entre los ecosistemas.

Keywords: Canis latrans; Coprophanaeus; Didelphis marsupialis; Eira barbara; food web; leaf litter; Nasua narica; Philander opossum; rainforest; scarabaeidae.

(c) 2020 Asociación Mexicana de Mastozoología, www.mastozoologiamexicana.org

\section{Introduction}

Scavenging is a mode of feeding in which organisms acquire nutrients from carrion. Obligate scavengers, such as vultures, rely entirely on carrion as a food resource, whereas facultative scavengers acquire some, but not all of their nutritional needs from carrion. Scavenging is phylogenetically widespread in vertebrates and invertebrates, and plays an essential role in terrestrial ecosystems. For instance, this mode of feeding is crucial for the recycling of energy and matter in food webs, and for accelerating nutrient cycling and widely distributing these nutrients across the landscape (Putman 1978; Braack 1987; DeVault et al. 2003; Selva and Fortuna 2007; Parmenter and MacMahon 2009; Barton et al. 2013). In addition, scavenging can have extensive consequences for the shape and stability of food webs (Wilson and Wolkovich 2011;
Beasley et al. 2015), and have far-reaching effects on organisms and populations, including shaping the evolution of behavior, social systems, and inter- and intra-specific interactions (Cooper 1991; Shivik 2006; Krofel et al. 2012; Moleón et al. 2014; Allen et al. 2015).

Due to its nutrient-rich, yet spatially and temporally patchy distribution, carrion is a unique resource that can have important effects on soils (Bump et al. 2009), microbes (Yang 2004), plants (Towne 2000; Bump et al. 2009), trophic webs (Barton et al. 2013), nutrient cycling and species diversity (Hocking and Reynolds 2011; Olson et al. 2012; Barton et al. 2013). Large and small-scale habitat differences can affect the fate of carrion, and ultimately its availability for, and monopolization by scavengers (DeVault and Rhodes 2002; DeVault et al. 2004; DeVault et al. 2011; Turner et al. 2017; Pardo-Barquín et al. 2019; 
Stiegler et al. 2020). For example, Houston (1985) found that carrion persisted longer for vertebrate scavengers in Neotropical rainforests compared to Afrotropical forests. Factors such as temperature, humidity, rainfall, season, and the composition of the insect community can affect the rates at which decomposers utilize carcasses (Houston 1985; DeVault et al. 2003; Selva et al. 2005; Selva and Fortuna 2007), and thus the availability of this food source to scavengers (DeVault et al. 2003).

Carrion availability can vary greatly within and across terrestrial ecosystems, and depends on the cause of mortality and the accessibility of the carcass location (Moleón et al. 2019). Empirical data showcasing the prevalence of carrion biomass in different ecosystems are scarce (DeVault et al. 2003; Barton et al. 2019; Moleón et al. 2019). The proportion of mortality due to predation versus other causes probably results in an important amount of food for scavengers, making it likely that more energy is transferred through scavenging than predation in trophic webs (Wilson and Wolkovich 2011). The percentage of animal deaths due to causes other than predation is thought to be fairly high in many ecosystems: $>95 \%$ of reindeer deaths in northern Scandinavia (Tyler and Øristland 1995), 25 to $88 \%$ for large mammals in a Polish forest (Jedrzejewski et al. 1993), 70 \% for large ungulates in the African savannah (Houston 1979).

However, the availability and utilization of small-mammal carcasses is inherently more difficult to determine. Due to their size, small-mammal carrion can be consumed entirely by a scavenger and disappear more quickly. Small-mammal carrion may be more difficult to detect (by scavengers or researchers), especially in a structurally-complex habitat. Some estimates calculate that $\sim 40 \%$ of small-mammal mortality is made available to scavengers and decomposers (Akopyan (1953) as referenced by Putman (1976) and DeVault et al. (2003). Oksanen et al. (1997) showed 83 to $98 \%$ of small-mammal deaths in the Arctic were not due to predation. Undoubtedly, the large reproductive output of most small mammals likely provides a large number of carcasses (Cowles and Phelan 1958). However, this does not show the importance of the energetic link between small-mammal populations to the scavenger community.

Even though scavenging is a widespread and important ecological process, it is poorly understood, underestimated, or overlooked in food web models (Wilson and Wolkovich 2011; Barton et al. 2013, Moleón et al. 2014), stemming in part by the difficulty in quantifying carrion in ecosystems (Barton et al. 2019; Moleón et al. 2020). Additionally, the role of scavenging in ecosystems has been oversimplified, with facultative scavenging often categorized as random or opportunistic, although research is now showing highly nested patterns and complex interactions dictating scavenger community structure (Selva and Fortuna 2007; Olson et al. 2016). In particular, we lack a comprehensive understanding of the fundamental role of scavenging in various ecosystems (Beasley et al. 2019), and the factors that shape and structure scavenging communities and scavenger behavior (DeVault et al. 2003; Wilson and Wolkovich 2011; Barton et al. 2013). For instance, despite facultative scavengers being more common than obligate scavengers, they are neglected in trophic studies. This is due, in part, to facultative scavengers described typically as predators or omnivores, and their roles as scavengers being unknown or ignored (Wilson and Wolkovich 2011). Scavenging by vertebrates is underestimated (Wilson and Wolkovich 2011; Barton et al. 2013), as scavenging research has often focused on arthropod scavenging (Barton et al. 2013). Additionally, research on understanding the species diversity and composition of the scavenger communities is timely, as they have been negatively affected by global change (Olson et al. 2012; Beasley et al. 2015; Buechley and Şekercioğlu 2016), and anthropogenic influences can drive changes in scavenger assemblages (SebastiánGonzález et al. 2019; Sebastián-González et al. 2020). Therefore, in order to better model food web dynamics, understand the intricate ecology of terrestrial ecosystems, and restore ecosystem services, it is important for scavenging to be quantified, and for scavengers to be identified.

Studies focused on elucidating the role and patterns of scavenging in Neotropical ecosystems are also lacking (Beasley et al. 2019; Sebastián-González et al. 2019). This is particularly true for understanding the dynamics and contribution of vertebrate scavengers and smallmammal carrion in these complex ecosystems. Studies that investigate scavenging in the Neotropics have focused mostly on arthropods or vultures, or have detailed scavenging observations of single species (Houston 1985; Houston 1986; Houston 1988; Lemon 1991; Gomez et al. 1994; O’Donnell 1995; VillegasPatraca et al. 2012; Mallon et al. 2013; dos Santos et al. 2014; Arroyo-Arce et al. 2016; Ucha and Santos 2017; Romero et al. 2020). Scavenging is thought to be significant in Neotropical forests. Houston (1986) estimated in Barro Colorado Island, Panama, that $4.1 \mathrm{~kg} / \mathrm{km}^{2}$ of mammals die every day. This amount surpasses those calculated for Afrotropical forests: 4.3 times higher than Lombe Forest, Cameroon and 1.58 times higher than Kibale Forest, Uganda (Houston 1985). Even though some proportion of these deaths is due to predation (Houston 1985) a large amount of carcasses would be made directly available to the scavenger community.

The goals of this project are to understand the importance of small-mammal carrion, scavenging, and factors that affect scavenging rates in a mid-elevation Neotropical rainforest. Specifically, I aim to study: 1) What are the rates of small-mammal carcass removal? 2) How does visual conspicuousness (position in the leaf litter) and size of the carcass affect scavenging rate? 3 ) What vertebrates are involved in scavenging the small-mammal carcasses? I use an experimental approach to explore these questions by placing fresh rodent carcasses above and below the leaf litter, along with trail cameras. This project provides insight 
into the importance of small-mammal carrion as part of the food-web dynamics of mid-elevation tropical rainforests.

\section{Materials and methods}

I conducted this study in Las Brisas Nature Reserve $\left(10.0670^{\circ}\right.$, $\left.-83.6376^{\circ}\right)$, Limón province, Costa Rica. Las Brisas is situated in the northeastern slopes of the Volcán Turrialba, within the central volcanic range of Costa Rica. The elevation in the reserve is $650-1,030 \mathrm{~m}$ above sea level, situating it as a mid-elevation forest. Las Brisas is composed of a mixture of old growth and secondary forests of various stages, along with some scrub and open areas. The reserve is located on a continuous range from the Caribbean lowlands to the highlands of VolcánTurrialba (https://www.lasbrisasreserve. com/aboutus). Access to the reserve is limited because it is privately owned and maintained, and although there is a system of trails, human presence is relatively limited.

To assess scavenging rates I set out and surveyed 194 mouse carcasses (Mus musculus) within the forested area of the Las Brisas Nature Reserve from 29 May through 8 June 2018. I purchased commercially available euthanized and frozen feeder mice (mouse meals for pets such as snakes) from a local supplier. Mouse carcasses were thawed at room temperature approximately 1 to 2 hours prior to placement in the field. I handled all carcasses with latex gloves, and weighed the thawed carcasses before deploying them. The average carcass weight was $11.64 \mathrm{~g}(n=194$; $\mathrm{SE}=0.40 ; \mathrm{SD}=5.55$; median $=10.5$ ). The weight ranged from 3.4 to $25.8 \mathrm{~g}$. The carcasses had white pelage, which was the only mouse color available from the supplier, but also mimics the ventral pelage of several species found in these Costa Rican forests.

I placed the carcasses ventral side up in areas that were accessible by the trail system in Las Brisas. Carcasses were placed at a minimum of $50 \mathrm{~m}$ from each other, 0 to $5 \mathrm{~m}$ off the trails. To test how visual conspicuousness affects scavenging rates, I placed 98 carcasses on top of the leaf litter and 96 below the leaf litter. To conceal the carcasses below the leaf litter, I moved fallen leaves with a stick, placed the carcass on the ground and covered it fully with the displaced leaves. After deploying the carcasses, I surveyed them daily until they had disappeared or had decomposed past the point of having any flesh remaining, which is how I determined carcass removal time (days elapsed since carcass deployment) since trail cameras are not triggered by invertebrates.

In addition to the daily sampling, I also placed trail cameras on each deployed mouse carcass to document scavengers. I used Ltl Acorn 5210-A (Guangdong, China) and Foxelli Outdoor Gear Oak's Eye Trail Camera (Vlaardingen, The Netherlands), on the most sensitive triggering settings, to record video for 30 seconds with no lapse time between videos. Trail cameras were set to trigger based on motion. The cameras were placed on existing structures within the forest a few meters away from the deployed carcass to identify scavengers. Although I attempted to set a camera on each deployed carcass, human error or equipment malfunction allowed me to get video recordings from 160 deployments. When reviewing the videos, I was conservative when identifying scavengers; animals were only categorized as scavengers if they were seen grabbing or consuming the carcass on the video.

Throughout the project I noticed that small mounds appeared where many carcasses had been deployed, and it was not until later in the experiment that I realized that something too small to be picked up by the trail cameras was burying the mouse carcasses. To investigate what was doing this, I dug below a few of the mounds and was able to follow narrow tunnels to my deployed carcasses buried $\sim 15$ to $20 \mathrm{~cm}$ deep. Attached to one of the buried mice were two Coprophanaeus corythus (Scarabaeidae) beetles. Unfortunately, I did not start recording data on whether beetles were burying the carcasses until too late into the study, but a large proportion of my carcass deployments exhibited the unique dirt mounds.

I used a general linear model to test the effect of weight (continuous independent variable) and position on the leaf litter (categorical independent variable above or below) on carcass removal time (dependent variable - transformed data on days elapsed since carcass deployment). I transformed the dependent variable of days elapsed since deployment to eliminate heteroskedasticity by taking the natural logarithm of the values plus one. I calculated carrion consumption rate, a measure of carrion biomass consumed divided by consumption time (g/ $\mathrm{hr}$ ), for carcasses in the two leaf litter treatments (above and below), and all data combined. I used MiniTab v. 18 for all statistical analyses. This study was approved by the University of Wisconsin's IACUC committee and Las Brisas Nature Reserve management, and permits were issued by Costa Rica's government agency MINAE.

\section{Results}

Scavengers removed the majority of mouse carcasses throughout the study. Of 194 carcasses placed in the forest, 193 (99.48\%) were removed by vertebrate or invertebrate scavengers, and only one was fully consumed by decomposers. Although I did not quantify the efficiency of beetles in burying carcasses, their ubiquitous mounds suggest they were dominant in monopolizing this resource. Only one carcass, placed below the leaf litter, decomposed and left behind remains of fur and bones six days after deployment. When all data are pooled together, the average number of days for carcass removal by scavengers is 1.57 days $(\mathrm{SE}=0.05 ; \mathrm{SD}=0.71$; median $=1$ ). Over half (54.12\%) of the mouse carcasses were removed within 24 hours, and $90.21 \%$ of carcasses were removed within 48 hours (Figure 1). The average consumption rate was higher for carcasses placed above ground $(0.396 \mathrm{~g} / \mathrm{hr}$; $\mathrm{SE}=0.022 ; \mathrm{SD}=0.221)$ than those placed below the leaf litter $(0.306 \mathrm{~g} / \mathrm{hr} ; \mathrm{SE}=0.017 ; \mathrm{SD}=0.174)$; overall carrion consumption rate was $0.352 \mathrm{~g} / \mathrm{hr}(\mathrm{SE}=0.014 ; \mathrm{SD}=0.204)$. 


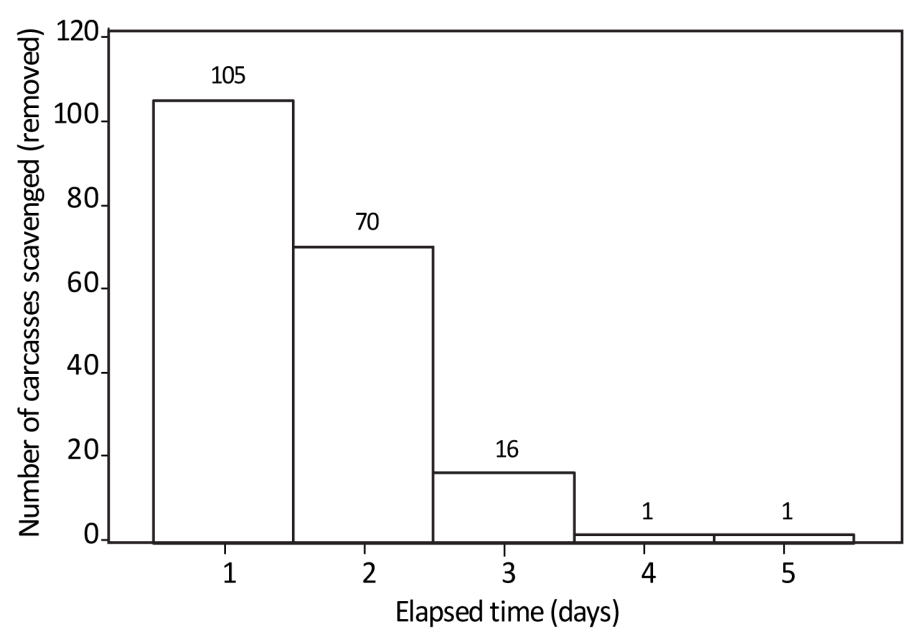

Figure 1. Histogram of number of carcasses removed by days after carcass deployment using all data pooled together.

The general linear model, with time to carcass removal as the dependent variable, shows a significant difference for both independent variables: weight $(n=194 ; \mathrm{F}=$ 8.67; $P=0.004)$, and position on the leaf litter $(n=194 ; \mathrm{F}$ $=19.58 ; P<0.001 ;$ Figure 2 ). The model summary shows an R-squared of $12.77 \%$. Weight had a small significant effect (regression slope for above and below leaf litter = 0.01521 ) resulting in larger carcasses lasting slightly longer. Overall, the carcasses placed above the leaf litter are removed more quickly than those below the leaf litter. The average number of days until the removal of a carcass placed above the leaf litter is 1.35 days $(n=97 ; \mathrm{SE}=0.06$; $\mathrm{SD}=0.63$; median $=1$ ). For these carcasses, $70.1 \%$ were removed by 24 hours, and $96.9 \%$ by 48 hours (Figure 3 ). The maximum number of days before a scavenging event for carcasses above the leaf litter is five days. In contrast, the average number of days until the removal of a carcass placed below the leaf litter is 1.78 days ( $n=96, \mathrm{SE}=$ 0.07 ; SD $=0.73$; median $=2$ ). Removal rate for carcasses placed below the leaf litter is $38.5 \%$ within 24 hours, and $83.5 \%$ within 48 hours. The maximum number of days before scavenging for carcasses under the leaf litter is 4 (Figure 4). The regression equation for carcasses placed above the leaf litter is $\operatorname{Ln}$ (days until removal +1 ) $=0.0631$ $+0.01521 \times$ weight. The regression equation for carcasses placed below the leaf litter is Ln (days until removal +1 ) = $0.3163+0.01521 \times$ weight.

Out of the videos captured on 160 carcass deployments, 10 videos showed a scavenging event by a vertebrate (6.25\%). The most common vertebrate scavenger recorded was the common opossum (Didelphis marsupialis), followed by gray four-eyed opossum (Philander opossum) and coyote (Canis latrans). Four videos showed a Russet-naped WoodRail (Aramides albiventris) pecking at carcasses, but not consuming the entire carcass. In five videos a variety of ver-
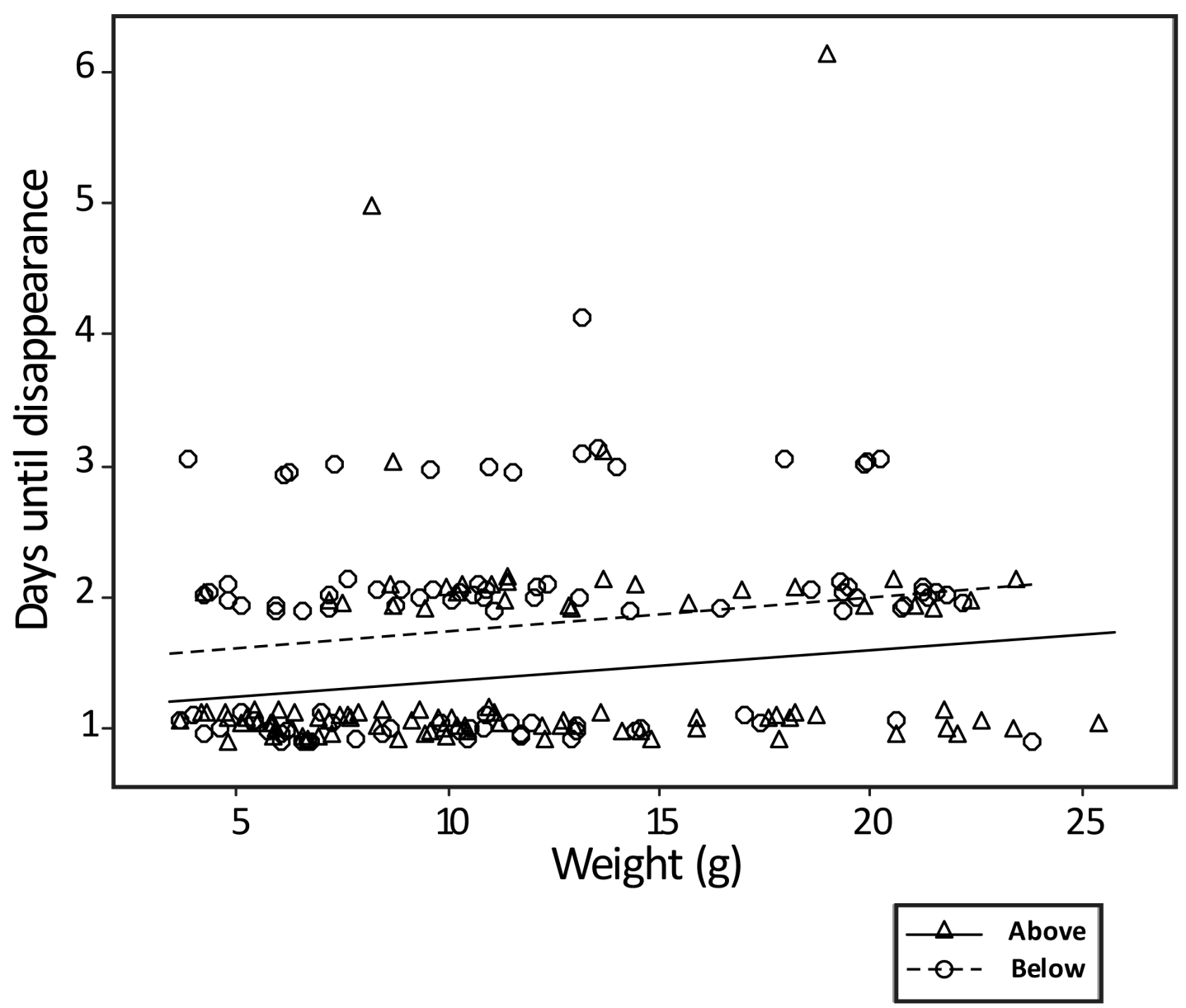

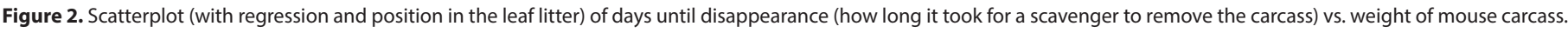




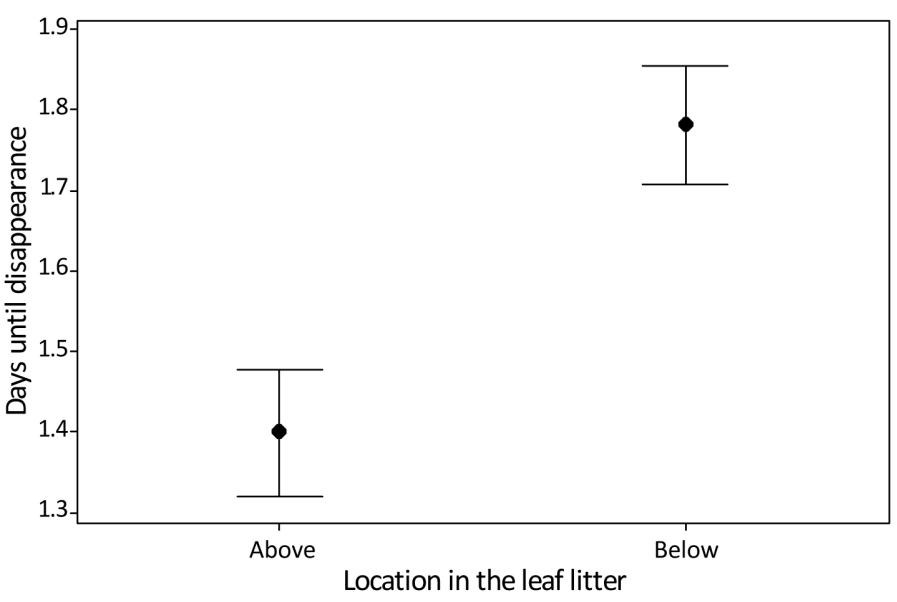

Figure 3. Interval plot of days until disappearance (how long it took for a scavenger to remove the carcass) vs. location in the leaf litter. Dot represents the mean. Error bars are one standard error.

tebrates are seen exploring and sniffing intently the area where the carcass was located, or had been located prior to disappearance. These videos showed tayras (Eira barbara), coatis (Nasua narica), and Russet-naped Wood-Rails interacting with the carcass or sniffing and searching where the carcass had been deployed (Table 1).

\section{Discussion}

Small-mammal carcasses were removed very quickly in this study (1.57 days on average), and only one carcass decomposed in place. The proportion of carcasses removed in the first days, show that carrion is an important and sought-after resource in these Neotropical rainforests.
Indeed, the time to carcass removal was assuredly overestimated since the presence/absence of the carcass was determined via surveys that were only conducted every 24 hours. The speed at which carrion is monopolized can vary by habitat type and ecosystems (Beasley et al. 2015); studies in temperate regions show a wide range of carcass disappearance speed for small-mammal carrion, but are typically longer than that reported here: $2.58,5.6$, and $1.23-$ 3.30 days (DeVault and Rhodes 2002; DeVault et al. 2004; Olson et al. 2012). Research done in the Neotropics with domestic chickens found a quick carcass removal time of $\sim 10$ hours (Houston 1986; Houston 1988). Temperature and humidity in the tropics likely create conditions in which microbes colonize carcasses quickly, and olfactory cues that can alert scavengers of carrion are emitted more quickly. Competition between a wide range of scavengers and decomposers is seemingly high.

One of the most striking aspects of this study is the relatively few instances of recorded scavenging by vertebrates. My study's rate of efficiency by vertebrate scavengers $(6.25 \%)$ is much lower than those reported in the literature. Although differences exist based on the location of the study, and the type and size of carcass used, published estimates of vertebrate scavenging efficiency in terrestrial habitats averages $\sim 75 \%$, and ranges from $13 \%$ to $100 \%$ (DeVault et al. 2003). If we focus on research that only utilizes small mammals as carrion bait, vertebrates are also the dominant scavengers, ranging in efficiency from $35 \%$ to 100 \% (Mullen and Pitelka 1972; DeVault and Rhodes 2002;

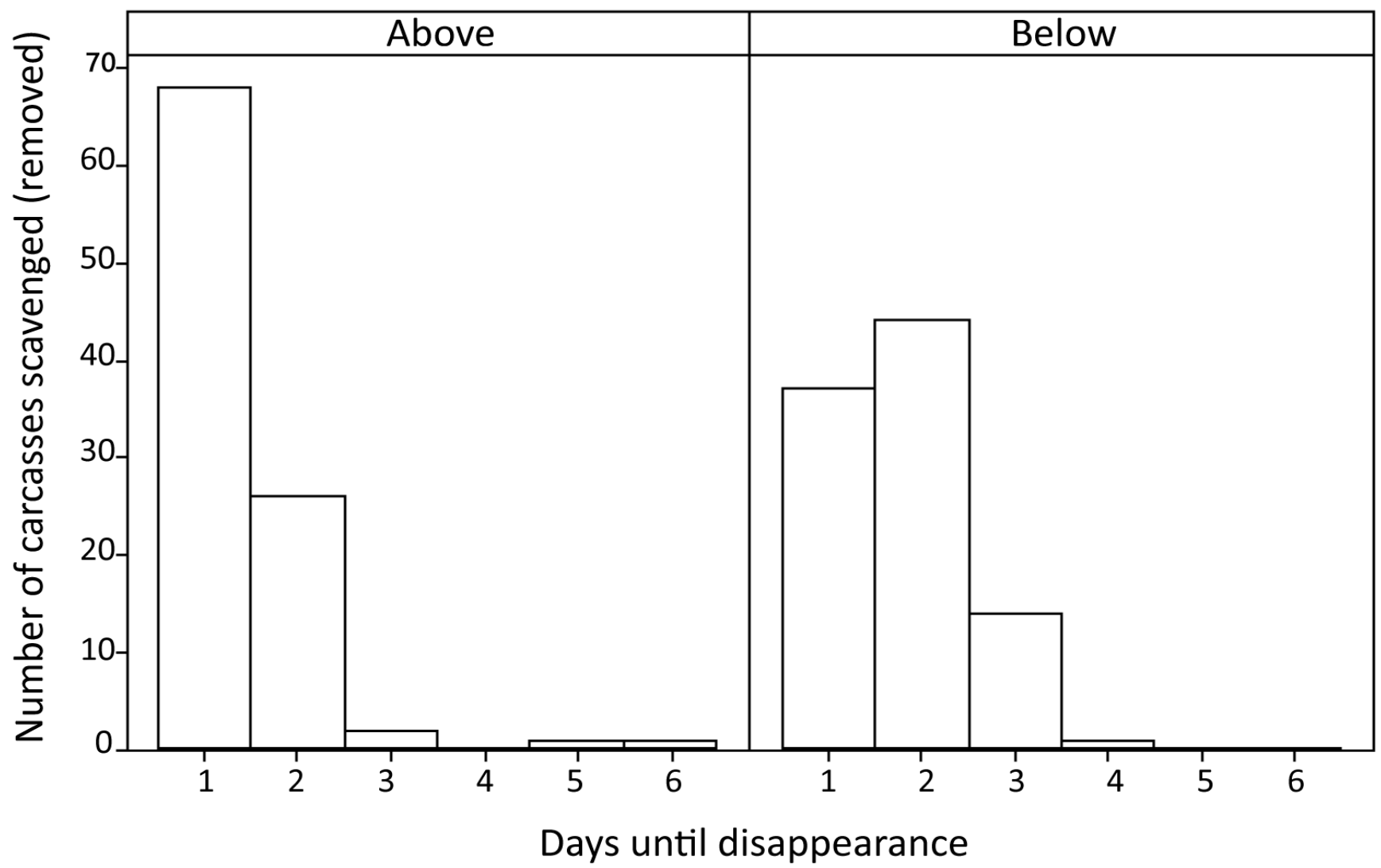

Figure 4. Histograms of number of carcasses removed by days after carcass deployment for above and below the leaf litter. 
Table 1. Vertebrate scavengers and their activity at carcass location.

\begin{tabular}{llll}
\hline \multicolumn{1}{c}{ Common name } & \multicolumn{1}{c}{ Species } & Number seen & Interaction with carcass \\
\hline Common opossum & Didelphis marsupialis & 6 Scavenging \\
Russet-naped Wood-Rail & Aramides albiventris & 4 Pecking at carcass, but not consuming or removing it \\
White-nosed coati & Nasua narica & 3 Sniffing near carcass or where carcass had been located \\
Coyote & Canis latrans & 2 Scavenging \\
Gray four-eyed opossum & Philander opossum & 2 Scavenging \\
Tayra & Eira barbara & 2 Sniffing near carcass or where carcass had been located \\
\hline
\end{tabular}

DeVault et al. 2003; DeVault et al. 2004; DeVault et al. 2011; Turner et al. 2017). Given the large number of deployments that had working trail cameras during pickup, equipment malfunction is unlikely to be the reason why we see this trend. It is, however, probable that the small-mammal carcasses were consumed or removed by invertebrates too small to activate the camera.

Invertebrate scavengers can consume high proportions of carcasses compared to vertebrates (Cornaby 1974; Ray 2014), and beetles were likely a strong force in the removal of whole carcasses during this study. Although I did not quantify the removal of carcasses by beetles from the start of the study, I did notice many conspicuous mounds in the carcass deployment locations. Similar research in a Costa Rican lowland forest showed that 70\% of small-mammal carcasses deployed on the ground were removed by beetles (Romero, unpublished data).

The results of this study pertaining to carcass weight are also probably a function of the interaction between the beetles and the carcasses rather than the vertebrate scavengers. We know that for the biomass of small-mammal carcasses, Coprophanaeus beetles are more effective in quickly locating and hoarding this resource. Given the regression equations, the smallest deployed mouse (3.4 g) would have been consumed or buried on average 8.18 hours quicker than the largest mouse $(25.8 \mathrm{~g})$. Very little ecological and behavioral information is available for these beetles (Edmonds 2010), and it is not known how long they take to bury a mouse carcass. The Coprophanaeus corythus beetles I found were very small ( 25 mm), so it is not hard to imagine that larger carrion would generally take longer to bury. At some point carcass size would become limiting to the beetles' ability to bury and exploit carrion. There must be a threshold at which these beetles no longer bury carcasses, and vertebrate scavenging may become more dominant, which may result in carrion partitioning, a pattern documented in other scavenging systems (see Moleón et al. 2017; Muñoz-Lozano et al. 2019).

How scavengers detect and locate carrion may be critical to understanding how this system of scavengers is maintained. Some research supports the idea that visual conspicuousness is important for scavengers to locate carrion (Selva et al. 2005). Olfactory cues, however, may be more important in attracting a suite of vertebrate scavengers to carcasses (Houston 1986; DeVault and Rhodes 2002; Potier et al. 2019). DeVault and Rhodes (2002) did not find a significant difference in the rates of scavenging on carcasses placed above and below leaf litter. Houston (1986) found that Neotropical vultures were able to locate the general area where chicken carcasses had been deployed above and below the leaf litter, and vultures were able to consume these carcasses within hours regardless of their leaf-litter position. My study found a difference in the time to removal of carcasses placed above and below the leaf litter, although the proportion of carcasses removed by scavengers (compared to entirely decomposing) was almost $100 \%$ for both. In addition, it is important to note that while carcass time to removal was significantly different for those placed above and below the leaf litter, carrion in both categories were scavenged relatively quickly, and the difference equated, on average, to only a matter of hours (above $=1.35$ days, below $=1.78$ days). This result may be due to microhabitat differences in relation to temperature, humidity, and exposure to direct sunlight (Sayer 2006), which affects the rate at which carcasses decompose and emit odor (Putman 1978; Shean et al.1993). As DeVault and Rhodes (2002) note, olfactory cues are likely important for mammalian scavengers; and both their study and mine recorded mammals sniffing in areas where carcasses had been placed but had already disappeared.

This study highlights the importance of small-mammal carrion as a sought-after resource in Neotropical rainforests. Carcass consumption rate may seem low (cf. SebastiánGonzález et al. 2016; Gutiérrez-Cánovas et al. 2020; Sebastián-González et al. 2020), but is most likely a function of the small carcass size. The speed at which small-mammal carcasses are entirely consumed or hoarded by scavengers is extremely fast. The relatively low rate of vertebrate scavenger efficiency in exploiting small-mammal carrion makes this ecosystem particularly unique. Further research should explore why beetles are seemingly outcompeting vertebrates. They may be locating these carcasses faster, detecting putrifaction cues at lower concentrations, or are simply highly abundant and able to arrive at the carcasses more quickly. While the efficiency of different scavenger guilds (vertebrates vs. beetles) can vary in different habitats, ecosystem function is typically sustained (Sugiura et al. 2013; Sugiura and Hayashi 2018). Therefore, research focused on understanding how these complex interactions between invertebrate and vertebrate scavengers maintain ecosystem function would be timely to help create a more developed framework for Neotropical food webs. 


\section{Acknowledgements}

This paper is in honor of Sydney Anderson, a fellow Jayhawk, for his great contributions to Neotropical mammalogy. I would like to thank E. Berlin, D. Berlin, and the staff of Las Brisas Nature Reserve for their support and assistance with this project. I'd also like to thank D. Brenes and B. Kohlmann, who offered expertise in identifying beetles, B. J. $\mathrm{O}^{\prime} \mathrm{Neill}$ and A. Romero Jr for helpful comments on the manuscript, and MINAET for providing permits. T. A. O'Neill provided valuable IT support during the pandemic. This work was supported by the University of Wisconsin-Whitewater through startup funds for A. Romero, departmental funds from UWW's Biological Sciences, and the Research Apprenticeship Program (RAP). B. Vandermus, a participant of RAP, provided valuable image analysis.

\section{Literature cited}

Aкopyan, M. M. 1953. The fate of suslik corpses on the steppe. Zoologicheskii Zhurnal 32:1014-1019.

Allen M. L., L. M. Elbroch, C. C. Wilmers, and H. U. Wittmer. 2015. The comparative effects of large carnivores on the acquisition of carrion by scavengers. The American Naturalist 185:822-833.

Arroya-Arce, S., I. Thomas, and K. Cutler. 2016. King Culture (Sarcoramphus papa) scavenging of green turtle (Chelonia mydas) carcasses in Tortuguero National Park, Costa Rica. Vulture News 70:30-36.

Barton, P. S., S. A. Cunningham, D. B. Lindemayer, and A. D. MANNING. 2013. The role of carrion in maintaining biodiversity and ecological processes in terrestrial ecosystems. Oecologia 171:761-772.

Barton, P. S., M. J. Evans, C. N. Foster, J. L. Pechal, J. K. Bump, M. M. QuAGgiotTo, AND M. E. BenBow. 2019. Towards quantifying carrion biomass in ecosystems. Trends in Ecology \& Evolution 34:950-961.

Beasley, J. C., Z. H. Olson, and T. L. DeVault. 2015. Ecological role of vertebrate scavengers. Pp. 107-127 in Carrion ecology, evolution and their applications (Benbow, M. E., J. K. Tomberlin, and A. M. Tarone, eds.). USDA National Wildlife Research Center - Staff Publications. Boca Raton, U.S.A.

Beasley, J. C., Z. H. Olson, N. Selva, and T. L. DeVault. 2019. Ecological functions of vertebrate scavenging. Pp. 126-157 in Carrion ecology and management (Olea, P. P., P. Mateo-Tomás, and J. A. Sánchez-Zapata, eds.). Springer. Cham, Switzerland.

BRAACK, L. 1987. Community dynamics of carrion-attendant arthropods in tropical african woodland. Oecologia 72:402-409.

Buechley, E. R., AND Ç. H. ŞekercioĞLu. 2016. The avian scavenger crisis: Looming extinctions, trophic cascades, and loss of critical ecosystem functions. Biological Conservation 198:220-228.

Bump, J. K., C. R. Webster, J. A. Vucetich, R. O. Peterson, J. M. Shields, and M. D. Powers. 2009. Ungulate carcasses perforate ecological filters and create biogeochemical hotspots in forest herbaceous layers allowing trees a competitive advantage. Ecosystems 12:996-1007.

Cooper, S. M. 1991. Optimal hunting group-size: the need for lions to defend their kills against loss to spotted hyaenas. African Journal of Ecology 29:130-136.
Cornaby, B. W. 1974. Carrion reduction by animals in contrasting tropical habitats. Biotropica 6:51-63.

Cowles, R. B., and R. L. Phelan. 1958. Olfaction in Rattlesnakes. Copeia 1958:77-83.

DeV AULt, T. L., I. L. BrisBin, JR., AND O. E. Rhodes, JR. 2004. Factors influencing the acquisition of rodent carrion by vertebrate scavengers and decomposers. Canadian Journal of Zoology 82:502-509.

DeVault, T. L., Z. H. Olson, J. C. Beasley, and O. E. Rhodes, JR. 2011. Mesopredators dominate competition for carrion in an agricultural landscape. Basic and Applied Ecology 12:268-274.

DeVault, T. L., ANd O. E. Rhodes. 2002. Identification of vertebrate scavengers of small mammal carcasses in a forested landscape. Acta Theriologica 47:185-192.

DeV ault, T. L., O. E. Rhodes, and J. A. Shivik. 2003. Scavenging by vertebrates: behavioral, ecological, and evolutionary perspectives on an important energy transfer pathway in terrestrial ecosystems. Oikos 102:225-234.

dos Santos, W. E., L. T. Carniero, A. C. F. Alves, A. J. CreãoDuarte, AND C. F. Martins. 2014. Stingless bees (Hymenoptera: Apidae: Meliphonini) attracted to animal carcasses in the Brazilian dry forest and implications for forensic entomology. Sociobiology 61:490-493.

Edmonds, W. 2010. A taxonomic review of the neotropical genus Coprophanaeus Olsoufief, 1924 (Coleoptera: Scarabaeidae, Scarabaeinae). Insecta Mundi 129:1-111.

Gomez, L. G., D. C. Houston, P. Cotton, And A. Tye. 1994. The role of Greater Yellow-headed Vultures Cathartes melambrotus as scavengers in neotropical forest. Ibis 136:193-196.

Gutiérrez-Cánovas, C., M. Moleón, P. Mateo-Tomás, P. P. Olea, E. Sebastián-González, and J. A. Sánchez-Zapata. 2020. Large home range scavengers support higher rates of carcass removal. Functional Ecology doi:10.1111/1365-2435.13619.

Hocking M. D., AND J. D. Reynolds. 2011. Impacts of salmon on riparian plant diversity. Science 331:1609-1612.

Houston, D. C. 1979. The adaptations of scavengers. Pp. 263-286 in Serengeti, dynamics of an ecosystem (Sinclair, A. R. E., and M. N. Griffiths, eds.). University of Chicago Press, Chicago, Illinois.

Houston, D. C. 1985. Evolutionary ecology of Afrotropical and Neotropical vultures in forests. Ornithological Monographs 36:856-864.

Houston, D. C. 1986. Scavenging efficiency of turkey vultures in tropical forest. The Condor 88:318-323.

Houston, D. C. 1988. Competition for food between Neotropical vultures in forest. Ibis 130:402-417.

JęDRZeJeWskı, W., K. SChmidt, L. Milkowskı, B. JęDRZejewSKA, AND Н. ОкаRма. 1993. Foraging by lynx and its role in ungulate mortality: the local (Bialowieza Forest) and the Palaearctic viewpoints. Acta Theriologica 38:385-403.

KLeIN, B. C. 1989. Effects of forest fragmentation on dung and carrion beetle communities in central Amazonia. Ecology 70:1715-1725.

Krofel, M., I. Kos, and K. Jerina. 2012. The noble cats and the big bad scavengers: effects of dominant scavengers on solitary predators. Behavioral Ecology and Sociobiology 66:1297-1304.

Las Brisas Nature Reserve About Us. 2020. Retrieved from https://www.lasbrisasreserve.com/aboutus Accessed on January 17, 2020. 
Lemon, W. C. 1991. Foraging behavior of a guild of Neotropical vultures. The Wilson Bulletin 103:698-702.

Mallon, J. M., K. Swing, And D. Mosquera. 2013. Neotropical vulture scavenging succession at a capybara carcass in eastern Ecuador. Ornitología Neotropical 24:475-480.

Moleón, M., J. A. Sánchez-Zapata, N. Selva, J. A. Donázar, ANd N. Owen-Smith. 2014. Inter-specific interactions linking predation and scavenging in terrestrial vertebrate assemblages. Biological Reviews 89:1042-1054.

Moleón, M., C. Martínez-Carrasco, O. C. Muellerklein, W. M. Getz, C. Muñoz-Lozano, and J. A. Sánchez-Zapata. 2017. Carnivore carcasses are avoided by carnivores. Journal of Animal Ecology 86:1179-1191.

Moleón, M., N. Selva, M. M. Quaggiotto, D. M. Bailey, A. CortésAvizanda, AND T. L. DeVault. 2019. Carrion availability in space and time. Pp. 23-44 in Carrion Ecology and Management (Olea, P., P.Mateo-Tomas, and J.Sanchez-Zapata, eds.) Wildlife Research Monographs, vol. 2. Springer Nature. Cham, Switzerland.

Moleón, M., N. Selva, and J. A. Sánchez-Zapata. 2020. The components and spatiotemporal dimensión of carrion biomass quantification. Trends in Ecology \& Evolution 35:91-92.

Mullen, D. A., And F. A. Pitelka. 1972. Efficiency of winter scavengers in the Arctic. Arctic 25:169-248.

Muñoz-Lozano, C., D. Martín-Vega, C. Martínez-Carrasco, J. A. Sánchez-Zapata, Z. Morales-Reyes, M. Gonzálvez, and M. Moleón. 2019. Avoidance of carnivore carcasses by vertebrate scavengers enables colonization by a diverse community of carrion insect. Plos One 14:e0221890.

O'Donnell, S. 1995. Necrophagy by neotropical swarmfounding wasps (Hymenoptera: Vespidae, Epiponini). Biotropica 27:133-136.

Oksanen, L., M. Aunapuu, T. Oksanen, M. Schneider, P. Ekerholm, P. A. Lundberg, T. Armulik, V. Aruoja, and L. Bondestad. 1997. Outlines of food webs in a low arctic tundra landscape in relation to three theories on trophic dynamics. Pp. 351-373. in Multitrophic Interaction in Terrestrial Systems. Blackwell Scientific Publications, Oxford, England.

Olson, Z. H., J. C. Beasley, T. L. Devault, and O. E. Rhodes, JR. 2012. Scavenger community response to the removal of a dominant scavenger. Oikos 121:77-84.

Olson, Z. H., J. C. Beasley, And O. E. Rhodes, JR. 2016. Carcass type affects local scavenger guilds more than habitat connectivity. Plos One 11:e0147798.

Pardo-Barquín, E., P. Mateo-Tomás, and P. P. Olea. 2019. Habitat characteristics from local landscape scales combine to shape vertebrate scavenging communities. Basic and Applied Ecology 34:126-139.

Parmenter, R. R., And J. A. MacMahon. 2009. Carrion decomposition and nutrient cycling in a semiarid shrubsteppe ecosystem. Ecological Monographs 79:637-661.

Potier, S., O. Duriez, A. Célérier, J. L. Liegeois, and F. Bonadonna. 2019. Sight or smell: which senses do scavenging raptors use to find food? Animal Cognition 22:49-59.

Putman, R. J. 1976. Energetics of the decomposition of animal carrion. PhD thesis, University of Oxford, Oxford, England.

Putman, R. J. 1978. The role of carrion frequenting arthropods in the decay process. Ecological Entomology 3:133-139.

Ray, R. R., H. Seibold, and M. Heurich. 2014. Invertebrates outcompete vertebrate facultative scavengers in simulated lynx kills in the Bavarian Forest National Park, Germany. Animal Biodiversity and Conservation 37:77-88.

Romero, A., J. Montaño, A. Soto Cedeño, and G. Oliveros LAYoLA. 2020. First report of bullet ants (Parponera clavata) sequestering vertebrate carrion. Food Webs 24: e00151.

SAYER, E. J. 2006. Using experimental manipulation to assess the roles of leaf litter in the functioning of forest ecosystems. Biological Reviews 81:1-31.

Sebastián-González, E., M. Moleón, J. P. Gibert, F. Botella, P. Mateo-Tomás, P. P. Olea, P. R. Guimarães JR, and J. A. SánchezZaPATA. 2016. Nested species-rich networks of scavenging vertebrates support high level of interspecific competition. Ecology 97:95-105.

Sebastián-González, E., J. Magalhães Barbosa, J. J. Pérez-García, Z. Morales-Reyes, F. Botella, P. P. Olea, P. Mateo-Tomás, et AL. 2019. Scavenging in the Anthropocene: human impact drives vertebrate scavenger species richness at a global scale. Global Change Biology 25:3005-3017.

Sebastián-González, E., Z. Morales-Reyes, F. Botella, L. NavesAlegre, J. J. Pérez-García, P. Mateo-Tomás, P. P. Olea, et al. 2020. Network structure of vertebrate scavenger assemblages at the global scale: drivers and ecosystem functioning implications. Ecography 43:1143-1155.

Selva, N., JędreJeWsKA, B., W. JędrejeWski, and A. WaJrak. 2005. Factors affecting carcass use by a guild of scavengers in European temperate woodland. Canadian Journal of Zoology 83:1590-1601.

Selva, N., And M. A. Fortuna. 2007. The nested structure of a scavenger community. Proceedings of the Royal Society B Biological Sciences 274:1101-1108.

Shean, B. S., L. Messinger, ANd M Papworth. 1993. Observations of differential decomposition on sun exposed v. sun shaded pig carrion in coastal Washington State. Journal of Forensic Sciences 38:938-949.

Shivik, J. A. 2006. Are vultures birds, and do snakes have venom, because of macro- and microscavenger conflict? BioScience 56:819-823.

Stiegler, J., C. von Hoermann, J. Müller, M. E. Benbow, and M. Heurich. 2020. Carcass provisioning for scavenger conservation in a temperate forest ecosystem. Ecosphere 11:e03063.

Sugiura, S., R. TANaka, H. TaKı, And N. Kanzakı. 2013. Differential responses of scavenging arthropods and vertebrates to forest loss maintain ecosystem function in a heterogeneous landscape. Biological conservation 159:206-213.

Sugiura, S., ANd M. Hayash.. 2018. Functional compensation by insular scavengers: the relative contributions of vertebrates and invertebrates vary among islands. Ecography 41:1173-1183.

Towne, E. G. 2000. Prairie vegetation and soil nutrient responses to ungulate carcasses. Oecologia 122:232-239.

Turner, K. L., E. F. Abernethy, L. M. Conner, O. E. Rhodes Jr., AND J. C. Beasley. 2017. Abiotic and biotic factors modulate carrion fate and vertebrate scavenging communities. Ecology 98:2413-2424.

Tyler, N. J. C., AND N. A. Øritsland. 1999. Varig utstabilitet og bestandsregulering hos svalbardrein. Norsk Polarinstitutt Meddelelser 150:125-138.

Ucha, J. L., ANDT. G. SANTos. 2017. Death and life on the roadway: scavenging behavior of the green racer snake Philodryas 
patagoniensis (Girard, 1858)(Dipsadidae). Herpetology Notes 10:439-441.

Villegas-Patraca, R., S. Macías-Sánchez, I. MacGregor-Fors, and C. Muñoz-Robles. 2012. Scavenger removal: Bird and bat carcass persistence in a tropical wind farm. Act Oecologica 43:121-125.

Wilson, E. E., AND E. M. Wolkovich. 2011. Scavenging: how carnivores and carrion structure communities. Trends in Ecology and Evolution 26:129-135.

Wolf, J. M., AND J. P. GibBs. 2004. Silphids in urban forests: diversity and function. Urban Ecosystems 7:371-384.

YANG, L. H. 2004. Periodical cicadas as resources pulses in North American forests. Science 306:1565-1567.

Associated editor: Jorge Salazar-Bravo

Submitted: April 10, 2020; Reviewed: May 22, 2020;

Accepted: July 22, 2020; Published on line: September 11, 2020. 